日臨外会誌 $61 （ 9), 2362-2367,2000$

症例

腸間膜静脈血栓症をくり返した先天性低アンチトロンビンIII血症の 1 例

\author{
社会保険相模野病院外科 \\ 松村弘人羽鳥慎祐鹿原健
}

症例は50歳男性, 28 歳時上腸間膜静脈血栓症で空腸が壊死に楩り約 $150 \mathrm{~cm}$ 切除され た.その後両下肢深部静脈血栓症を発症したため凝固系の検查を行い先天性低 AT-III血 症と診断した. 45歳左下肢動脈閉塞を発症した以外平穏であったが1998年 7 月腹痛出現 しイレウス症状にて入院. 上腸間膜静脈血栓症の再発を強く疑ったが早期には確診しえ ず腹痛の持続と下血が生じたため入院 8 日目に手術を行ったところ小腸が二筫所血栓症 にて壊死に陥っていた。術後は AT-III製剤を使用しさらなる再発はみなかった。腸間膜 静脈血栓症では凝固系の精査（とくに AT-IIIの測定）を必ず行う必要がある.

先天性 AT-III欠乏症では静脈血栓を発生し易いし再発も多い. 無症状で経過している ものは血栓症への誘因, 要因を避ける指導でよいが一度でも静脈血栓症を発症した場合 には再発防止に備えクマリン系薬剮の継続投与が必要である.

索引用語：腸間膜静脈血栓症, 低 AT-III血症, 抗凝固療法

\section{緒言}

上腸間膜静脈血栓症の術後に右下肢深部静脈血栓症 を併発した. その後両下肢深部静脈血栓症を発症した ため凝固系の異常を疑い精査したところ, 先天性低 AT-III血症であることが判明した，その後静脈炎後遺 症による下腿謴場以外症状はなかったが22年後にイレ ウス症状て発症し黄疸を併発した上腸間膜静脈血栓症 の再発をみた症例を経験したので報告する.

$$
\text { 症例 }
$$

症例：50歳, 男性.

主訴: 腹痛, 嘔気, 嘔吐.

既往歴：28歳時上腸間膜静脈血栓症にて空腸が壊死 に陥つたため約 $150 \mathrm{~cm}$ 切除, 術後 5 日目右下肢深部静 脈血栓症に対し血栓摘除術後肺塞栓を併発 ${ }^{1)}$, 33歳右 下肢深部静脈血栓症再発, 34歳左下肢深部静脈血栓症, 35歳先天性低 AT-III血症と診断 ${ }^{2} ， 45$ 歳左下肢動脈閉 塞（図 1 ).

家族歴：図 2 に患者の家系図を示す。母と妹が低 AT-III血症で母親は患者を出産後両側下肢血栓性静 脈炎となったが妹は異常なし. 思者の次男, 長女が低

2000 年 2 月 21 日受付 2000 年 5 月26日採用

〈所属施設住所〉

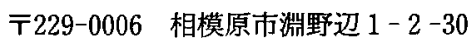

AT-III血症である.

現病歴：静脈炎後遺症による下腿潰瘍が再発し時々 通院していた. 1998年 7 月19日腹痛が出現し持統した ため 2 日後に来院, 入院した.

入院時現症: 嘔気, 嘔吐あり, 腹部は軽度膨満, 中 下腹部に压痛, 抵抗あるもデファンスははっきりしな かった.

入院時検査所見：血液一般生化学検査では白血球增 多 $\left(12300 / \mathrm{mm}^{3}\right)$ は認められたが他に異常なく, ATIII活性は $54 \%$ T゙ TAT は $49.7 \mu \mathrm{g} / 1$ であった。血液ガス 分析にてアチドーシスは認めなかった。

入院時腹部単純 $\mathrm{X}$ 線所見：ガス像はほとんど認めら れなかった。

CT 所見：拡張した腸管が認められた（図 3 ).

既往歴より腸間膜静脈血栓症が強く疑われたがとり あえずイレウスの診断で経過観察とした．入院後腹痛 は自制内で上腹部に圧痛，抵抗はあったがデファンス は認めなかった。しかし徐々にイレウス症状が増強し たためイレウスチューブを挿入した。その造影(図4) では造影剤は直腸にまで達しており単なる器質的腸閉 塞と診断できず手術にはふみきれなかった，腹痛は持 続し入院 4 日目より黄疸が出現した。超音波検查にて 胆型の腫大があり胆䉴炎が疑われた。その翌日には夕 ール便がみられた，比較的全身状態は保たれていたが 
自発痛は持続し黄疸 (T. Bil. $2.9 \mathrm{mg} / \mathrm{dl})$ ，イレウス症 状も軽快しないためやはり腸間膜静脈血栓症を否定し

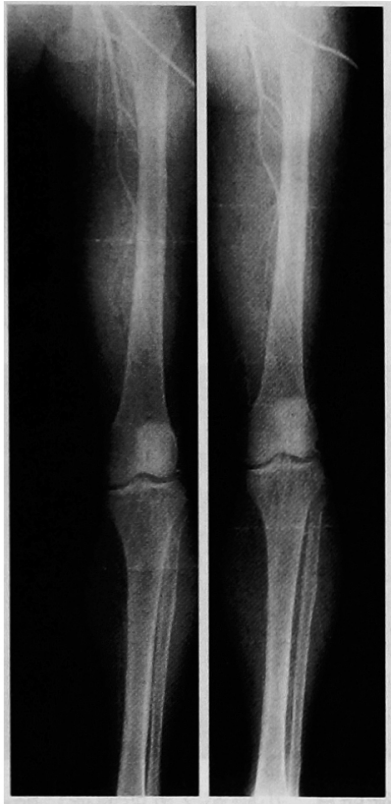

图 1 左下肢動脈造影：線維 素溶解醉素㓮による治療を 行ったが, 浅大腿動脈は閉塞 した.
えず入院 8 日目手術を施行した。

手術所見：正中切開にて開腹すると腹水はなく Treiz 靶帯より約 $40 \mathrm{~cm}$ の拡張した空腸が肛門側より 約 $20 \mathrm{~cm}$ の範囲で境界鮮明に壊死に陥っていた。腸間 膜には肉眼上血栓は認められなかった。さらに回腸末 端より約 $80 \mathrm{~cm} の$ 回腸が口側約 $10 \mathrm{~cm}$ 壊死に陷ってい た.おのおの切除再建し残存小腸は約 $180 \mathrm{~cm}$ であった (図 5 ).

病理組織学的所見：静脈を中心とした脈管拡張, 高 度の栓血と出血を伴っており内腔は腸管全層の急性の

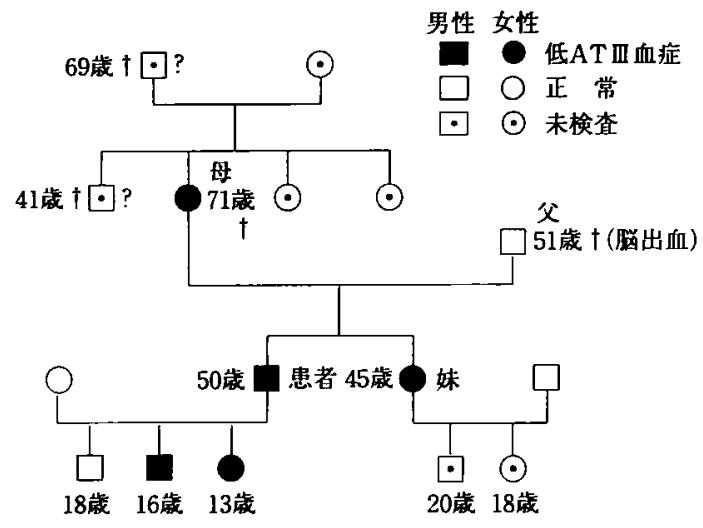

図 2 患者家系図

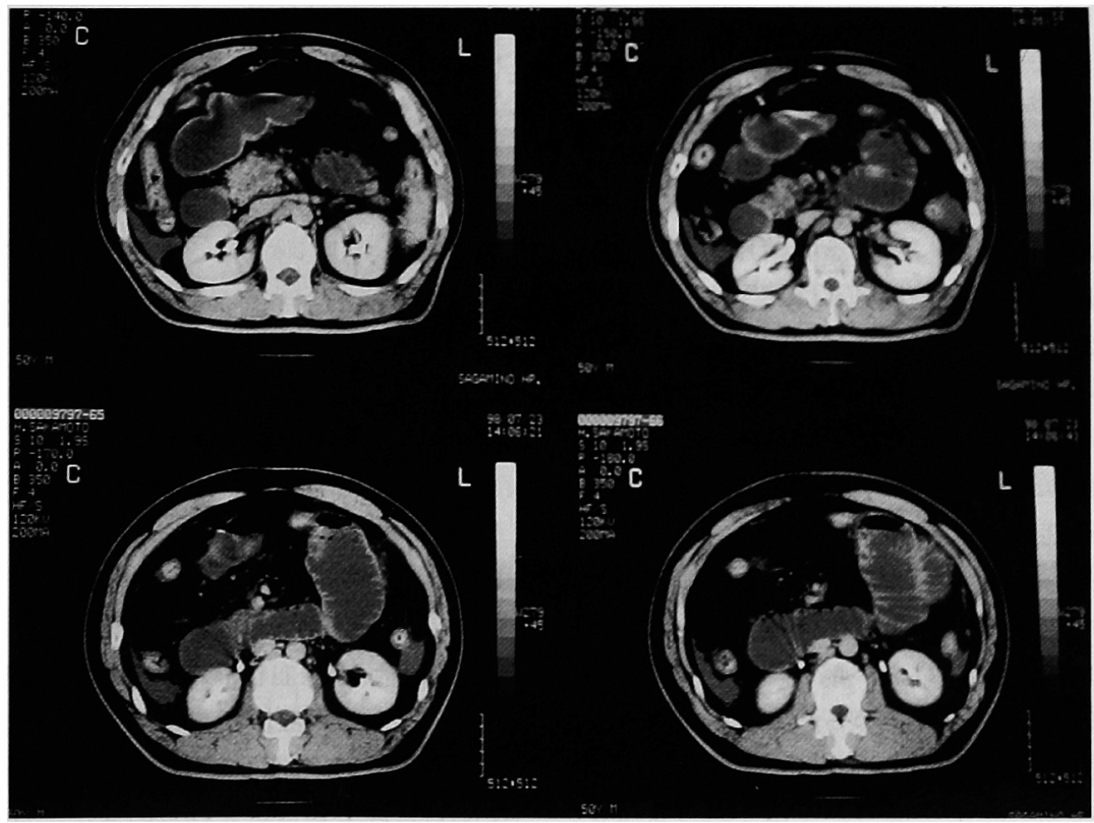

図 3 腹部 CT：抎張した腸管が認められた。 


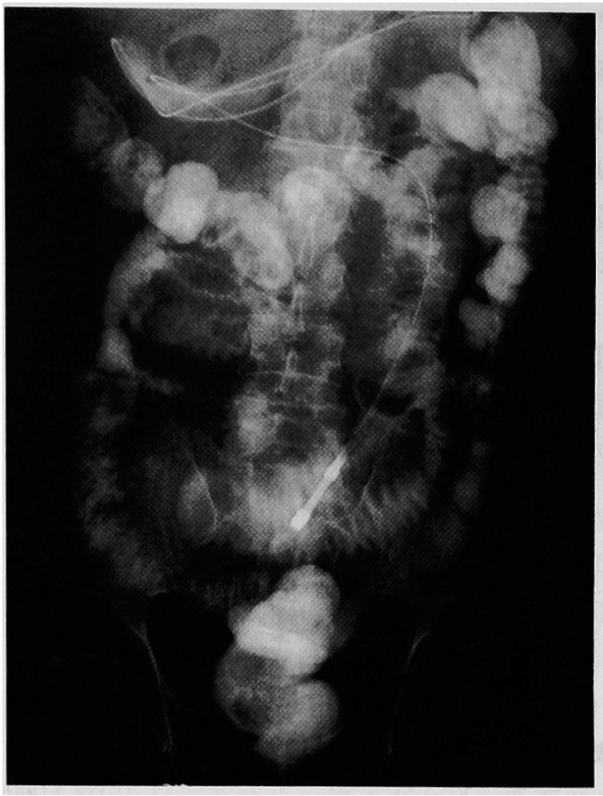

図 4 イレウスチューブよりのガストログラフ イン検査：直腸まで造影され通過障害は認め なかった。

虚血壊死であるが急性壊死部の周囲には潰瘍形成，獎 膜には線維化と毛細血管の増生があり亜急性の虚血が 起こっていたものと考えられた。一部の小中静脈内に 血栓形成を見るが内腔の閉塞には至っていない.また， より中枢部の血管の閒塞は明らかではなかった（図 6 ).

術後経過：術直後より AT-III製剂1500U と低分子 ヘパリン $5000 \mathrm{U}$ を 3 日間併用しさらに 3 日間 AT-III 製剂を使用し AT-III活性を $90 \%$ 前後に維持しえた（図 7 )。その後はワーファリン $3 \mathrm{mg}$ を開始したが開始後 10日目より下血が始まったため（TT8.8\%）胃内視鏡 検查を施行したところ胃噴門部に静脈瘤が認められた が出血はなかった，貧血および血小板も減少したため ワーファリンを中止した．自然に下血は止まったが血 小板減少が持続したためワーファリンの投与は中止し たままで術後41日目に退院した。しかし本例はさらな る血栓症の発生の可能性があり血小板減少は持続して いたが1999年 4 月よりワーファリンの投与を開始し現 在まで新たな血栓症の発生はないがいまだ静脈炎後遺 症による下腿潰㕫に悩まされている。なお，術前あっ た黄疸は術直後より消失した。この黄疸の発生は術中 胆䕉炎の所見はなかったことより，上部空腸が狭窄よ り閉塞に至ったイレウス状態で十二指腸の内圧が元進
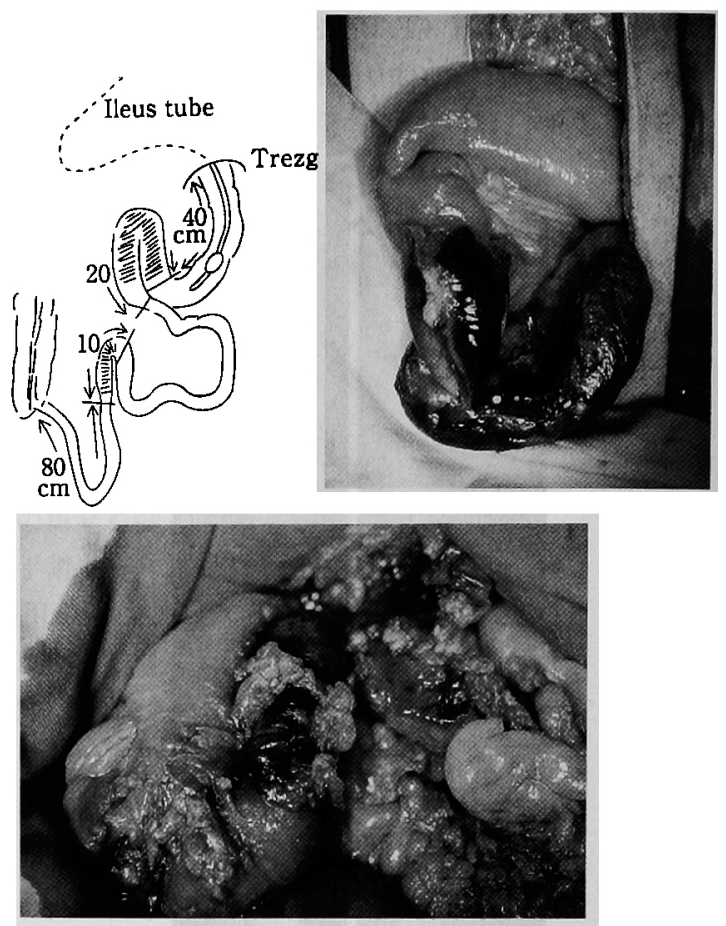

図 5 手術所見：小腸が 2 力所壊死に陥っていた。

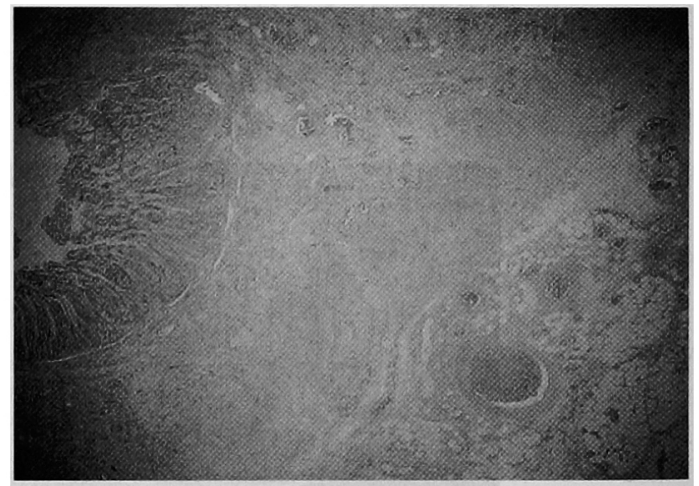

図 6 病理組織学的所見：静脈を中心とした脈管拡張, 高度の缽血と出血を伴い内腔は腸管全層の急性の虚血 壊死を示す。

し胆汁排泄が障害されたためと思われた。

\section{考 察}

上腸間膜静脈血栓症の本邦報告95例を向井ら

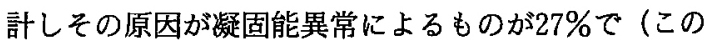
うちAT-III欠乏症は15\%)，52\%は特発性ないし原因 不明とされているがこれらのなかには凝固系の検査が なされていないものがあり，凝固能異常の割合はもう 


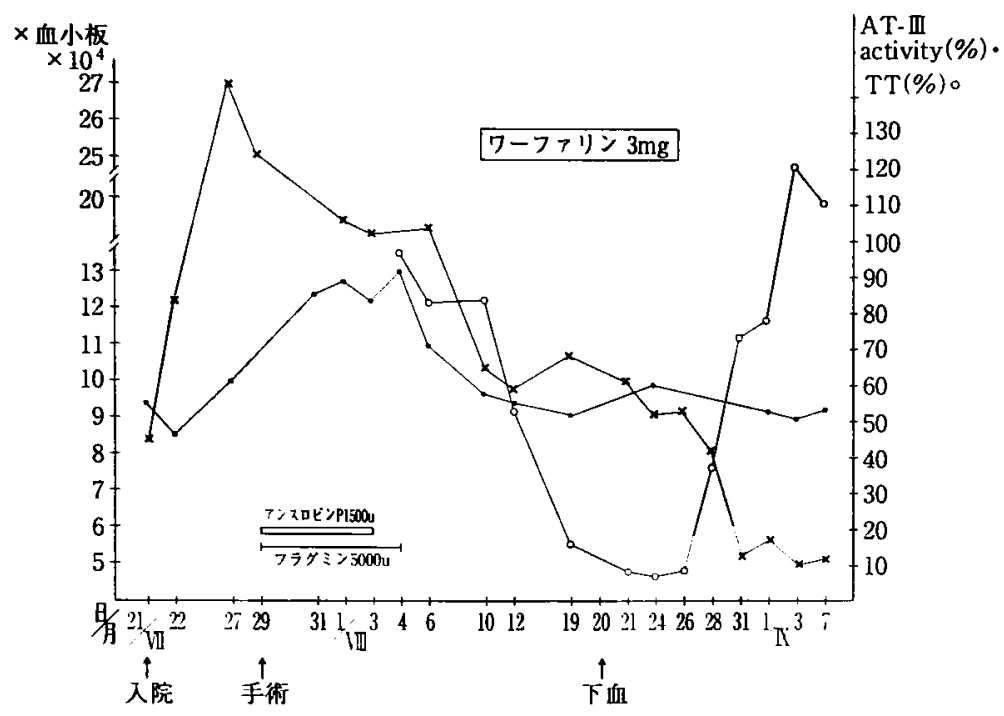

図 7 アンチトロンビンIII活性值（AT-III） $\left({ }_{0}^{\circ}\right)$ トロンボラスト (TT) $\left({ }_{0}^{0}\right)$ ，血 小板数の变化

少し多いであろうと報告している．本例も最初の発生 時には凝固系のチェックは行われていなかったし， AT-IIIレベルは測定時の病態によりかなり変動がみ られると思われるので境界領域の AT-III欠乏症は見 逃され特発性とされているものがかなりあると思われ

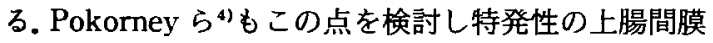
静脈血栓店が本当に存在するのかに疑問を呈示し，腹 腔内の静脈閉塞を示す症例においては AT-IIIの検索 を詳練に行うことを強調しているし，事実本例でも AT-IIレベルのかなりの変動が認められた。先天性 AT-III欠乏症注血栓症発生のリスクが非常に高く"1, その $65 \%$ に静脈血栓症の既往がみられるとされ うち下肢深部静脈血栓症の発症が最も多くついで腸間 膜静脈, 門脈, 肺動脈, 脳矢状静脈の血栓が報告され ているがで，本例にみられた下肢動脈の血栓の報告は みない. 本例は上腸間膜静脈血栓症に始まり両下肢深 部静脈血栓症を発症したため AT-IIIの検索を行い先 天性低 AT-III血症と診断した，その後も血栓症の絽り 返しで非常に stormy な経過をとりさらに今回腸間膜 静脈血栓の再発をみた。腸間膜静脈血桎症の早期診断 は困難なことが多いとされている9. 典型例は CT, US, 血管造影にて確診しうるが多くは症状に比し理学 的所見が弱いすなわち激しい腹痛に比較し腹部所見が そしいため早期診断が難しいのでまず本症を念頭にお くことが肝要と思われる. 事実本例の初発は中枢側の
静脈が閉塞し広範囲の壊死に至り腹痛が強度のわりに 腹膜刺激症状などの理学的所見が弱いという典型的な 本症の症状を呈したが，再発した今回は腸間膜静脈の 末梢に閉塞が 2 箇所において生じ比較的小範囲の壊死 でしかも徐々に進行したと思われ，腹痛も自制内で腹 部所見も軽度でありアチドーシスもなかったため腸間 膜静脈血栓症を疑いながらも確診しえず手術までに時 間を要した。かくのごとく本症は術後再発率が高いこ とも特異な点でありこれが予後に影響する. Jona ら ${ }^{10)}$ は腸管切除後の壞死再発率が $29^{\circ}$ 。 と報告しており, 本 邦での再発率は $16^{\circ}$ 。である9!。 また一般に本症では虚 血腸管と正常部分の境界が比較的不明瞭であることが 多いとされ切除部位の決定が困難で二次的な手術が必 要なことがあるとされているが本例では境界鮮明に壊 死に陥っていたので切除部位の決定は容易であった。 再発例で腸管切除が大量になった場合の予後において は短腸症候群が問題となるので再発を防ぐことが重要 である．先天性低 AT-III血症による本症の急性期(術 直後）の再発予防にはAT-III製郕の補充が必須であ る.へパリンの抗凝固作用は AT-III との相互作用によ るものでへパリンの単独投与では AT-IIIの消費が促 進され血獎 AT-III濃度の低下を助長するため適切で はない"11. 本例では術直後より AT-III製剤1500U/日， 6 日間使用し低分子へパリンを併用した．慢性期には AT-IIIの抗原量を高める作用をもつクマリン系薬剤 
(ワーファリン) を継続使用することが必要である6). 左下肢深部静脈血栓症で肺塞栓症を併発した後 12 年間 ワーファリンを服用していた患者が服用を中止して五 カ月後に腸間膜静脈血栓症を発症した報告があり ${ }^{12)}$, 低 AT-III血症で血栓症の既往がある場合にはワーフ アリンの継続は必須と思われる. 以上より本例にはも つと早期に抗凝固療法を継続しておくべきであったが 症状が安定すると定期的に来院せず 5 年間の無症状後 に腸間膜静脈血栓症の再発をみた。術後の検索で脾腫, 胃噴門部静脈瘤, 血小板隇少が持続しており門脈血栓 症も併発していると思われ，今後は致死に至る血栓症 の可能性もありクマリン系薬剤による抗凝固療法は不 可欠と思われる.

\section{結 語}

腸間膜静脈血栓症を初発としてその後血栓症の繰り 返しで極めて特異的な経過をとり，さらに腸間膜静脈 血栓症の再発をみた先天性低 AT-III血症の 1 例を報 告した。先天性低 AT-III血症で無症状のものは血栓症 への誘因, 要因について十分説明し兓重な経過観察と 指導管理でよいと思われるが一度でも静脈血栓症を発 生した場合は血栓症再発の可能性が強く, その発生部 位, 程度も種々であり治療に難渋し, 後遺症を残し予 後も不良となるので再発防止を念頭におくことが肝要 である．そのためには生涯クマリン系薬戍による管理 が大切であることを強調したい.

なお，本論文の要旨は第61回日本臨床外科学会総会にて 発表した.

\section{女 献}

1) 小林 理, 須田 嵩, 城島標雄他: 特発性腸間膜 静脈血栓症の 1 治験例. 外科 $30: 1564-1566$, 1977

2）松村弘人, 戸部道雄, 長井孝夫他：先天性低アン チトロンピン血症を伴う下肢静脈血栓症の 1 例.
外科 $46: 174-177,1984$

3）向井秀泰, 石川隆一, 松本京一他: アンチトロン ビンIII（AT-III）欠乏症によると思われる上腸間 膜静脈血栓症の一例. 日救急医会関東誌 $18: 44$ $-45,1997$

4) Pokorney BH, Eyster MH, Jeffries GH : Antithrombin III Deficiency Appearing as Mesenteric Vein Thrombosis. Gastroenterology 76 : 534537, 1981

5) Wilson C, Walker ID, Davidson JF, et al: Mesenteric venous thrombosis and antithrom. bin III deficiency. J Clin Pathol 40:906-908, 1987

6）石井良幸, 渡辺昌彦, 山本聖一郎他：先天性 ATIII欠乏症を伴う腸間膜静脈血栓症, 術後腸閉塞症 の1手術例. 日消外会誌 $30: 2307-2311,1997$

7）松尾 理：先天性アンチトロンビンIII欠乏症. 血 と脈管 $13: 17-25,1982$

8）村山英樹, 若林邦夫, 松田道生他：先天性低アン チトロンビンIII血症を伴う上腸間膜静脈血栓症の 2 例. 血と脈管 $13: 568-572,1982$

9）石井貴士, 島田長人, 柴 忠明：上腸間膜静脈血 栓症. 臨外 $52: 1543-1547,1997$

10) Jona J, Cummins GM Jr, Head HB, et al: Recurrent primary mesenteric venous thrombosis. JAMA $227: 1033,1974$

11）久住静代, 高田 昇, 小林 誠他: 先天性抗卜口 ンビンIII (AT-III) 欠乏症一プロテアーゼインヒ ビターの病態と補充療法の現況について一. 広島 医 $36: 971-977,1983$

12) Karl R, Garlich I, Zarius C, et al: Surgical implications of antithrombin III deficiency. Surgery $89: 429-433,1981$ 


\title{
A CASE OF RECURRENT MESENTERIC VENOUS THROMBOSIS WITH CONGENITAL ANTITHROMBIN III (AT-III) DEFICIENCY
}

\author{
Hiroto MATSUMURA, Sinsuke HATORI and Takesi KABARA \\ Department of Surgery, Shakaihoken Sagamino Hospital
}

This paper deals with a case of recurrent mesenteric venous thrombosis with congenital antithrombin III(AT-III) deficiency in a 50-year-old man. When he was 28 years a partial resection of the jejunum was performed because of necrosis of the small intestine due to superior mesenteric venous thrombosis (MVT). After suffering from deep venous thrombosis of the bilateral lower extremities, hematological studies disclosed low level of AT-III antigen and through further studies congenital AT-III deficiency was diagnosed. After that he was uneventful except for arterial thrombosis in the left lower extremity at the age of 45 .

In July 1998, he was admitted to the hospital with a suspicion of ileus. The recurrence of superior MVT was mostly suspected but correct diagnosis was not made. Upon admission, abdominal pain persisted and gross bleeding from the rectum was noted. After 8 days of admission, an emergency operation was performed. Two parts of the small intestine got into necrosis due to MVT. Postoperatively the patient received antithrombin III and no venous thrombosis was induced during post operative course.

Congenital deficiency of AT-III may predispose to thrombotic events. In case of no thrombotic episode, it may be enough to manage them keep away from causes and factors of venous thrombosis, but in case of thrombotic events, persistent long term management with warfarin therapy is mandatory in avoiding further thrombotic events. 